\title{
ZANG V TOT XII EN XV TOT XVII VAN DEN NĀGARAKRĔTĀGAMA.
}

DOOR

Prof. H. KERN.

\section{V.}

In Zang V, VI en VII weidt de dichter uit over de familieleden van Hayam Wuruk. Wat hij mededeelt is een te waardeeren anvulling van wat men leest in de Pararaton blz. 27 (in de vertaling blz. 118, vg.), en strekt in 't algemeen tot bevestiging vau de opgaven der kroniek.

Zang V, in Praharșinî-maat, begint aldus:

Wwantěn tāri haji ri Wilwatikta rājūī|

sang munggw ing Lasĕm anurāga ring kahaywan |

putrî̀ Çrì-narapați ring Daha prakāça |

sang Çrì-Rājasaduhitendudewy auindya $\|1\|$

D. i. "De heerscher van Wilwa-tikta (Majapahit) had als jongere zusters (de volgende): 1) de vorstin die resideerde te Lasěm, verrukkelijk van schoonheid; 2) de dochter van Z. Hoogh. den vorst van Daha, wijdvermaard, de dochter van $Z$. Hoogh. Rājasa, de onberispelijke Indudewī."

De tweede strofe luidt aldus :

Ndan Çrì-Warddhanaduhiteçwarì pamungsu |

rājūì munggw ing Pajang anopameng raras rūm |

putrì Çrì-urpati ri Jîwana prakāça |

an sākșāt anuja těkap nirang narendra $\|2\|$

D. i. "Voorts de vorstelijke dochter van Z. Hoogh. Wardhana ${ }^{1}$, de jongste, die vorstin was, resideerende te Pajang. onvergelijkelijk

1 Dezelfde als Krtawardhana in Zang III genoemd, de gemaal van H. Hoogheid te Kahuripan.

7० Volgr. IX. 
in behoorlijkheid en lieftalligheid, dochter van H. Kouinklijke Hoogh. te Jïwana (Kahuripan), wijdvermaard, als jongere zuster van den Koning."

Hayam had slechts twee jongere zusters, in eigenlijken zin, dochters van zijn vader Kụtawardhana en zijne moeder, Hare Hoogh. van Kahuripan, de vermaarde Regentes gedurende zijne minderjarigheid. Die twee zusters waren de vorstin te Lasĕm, en de andere die te Pajang bewind voerde. De eerste wordt in Pararaton betiteld als Bhreng Matahun, maar dit is te verklaren, omdat, gelijk uit den volgenden Zang blijkt, haar gemaal genoemd wordt: Heer van Matahun. Wat nu betreft de in de tweede plaats genoemde, Indudewi , deze was geen jongere zuster van Hayam Wuruk in den bloede, mar zijue vrouw: zij was dus de schoondochter van de Regentes, en in overdrachtelijken zin de jongere zuster, d.i. beminde vrouw, van den Koning, en tevens zijn volle nicht, want zij was de dochter van Rājasa = Wijayarājasa, den gemaạl van Bhreng Lasĕm, heerscheres vau Daha.

In den volgenden Zang lecren wij de echtgenooten der twee jongere zusters van Hayam Wuruk kennen.

\section{Z ang VI.}

Deze Zang is in Çārdūlawikrịtita :

Penak ${ }^{1}$ Crí-naranātha kapwa ta huwus labdhābhișeka prabhu| sang nātheng Matahun priya nrěpati sang rājyeng Lasěm suçrama | sang Çrî̀-Rājasa warddhana prakaçiteng rūpādhiwijñeng naya| tanpendah Smara Pinggalā patěmu sang nāthenalĕm ning jagat $\|$ l |

D. i. "Reeds hebben al de vorsten hun wijding tot vorst, naar wensch, outvangen. De vorst van Matahun is de gemaal vau de. wakkere vorstin die te Lajĕm heerscht, hij, Z. Hoogh. Rājasawardhana, bekend om zijn schoonheid, zeer ervaren in staatsbeleid. Het huwelijk van de (beide) vorstelijke personaadjes, door iedereen geprezen, is geheel als vau Smara (den Minnegod) met Pinggalā (d. i. Lakș̣̣î , de godin der Schoonheid)."

Hier vindt men de verklaring waarom in de Pararaton H. Hoogh. van Lasĕm den titel voert van Bhreng Matahun. Onder den titel Raden Larang, dien haar man in de Pararaton draagt, was hij zeker bekend vóór zijn huwelijk.

1 Penan in den tekst foutief. 
De tweede strofe vermeldt het huwelijk van de andere zuster, in deze bewoordingen :

Sang nātheng Paguhan priya nrěpati sang rājūī pratișțe Pajang | khyāti Çrì-ṇ̣pa Singhawarddhana surūpānwam suçìlāpagĕh | açry āwarṇna Sauatkumāra saha dewị̀̂a papanggih nira| bhakti jöng haji māsih awwang anak angde tuṣṭa ning nāgara \|| 2 \|

D. i. "De vorst van Paguhan is de gemaal van de koningiu die gevestigd is te Pajang; (hij is) bekend als Z. Hoogh. vorst Singhawardhana, schoon, jong, deugdzaam, ferm. ${ }^{1}$ Heerlijk is hun huwelijk als vâu Sauatkumāra met de godin Iḍā; onderdanig jegens de voeten des Heerschers, liefderijk jegens verwanten, de tevredenheid wekkende van de bewoners des rijks."

Ook in de Pararaton, blz. 27, staat te lezen dat de gemaal van H. Hoogh. van Pajang heette Z. Hoogh. van Paguhan. Als ziju Prinsemuaan wordt daar opgegeven Raden Sumana, wat de dichter niet vermeldt.

Uit de bewoordingen van den laatsten regel kan men opmaken, dat de zusters van Hayam Wuruk mitsgaders hun echtgenooten, ondanks hun hooge titels, ondergeschikt waren aan den heerscher van Majapahit; het waren, om zoo te zeggen, Pangerans, maar geen koniugen in onzen zin.

Iḍā, als figuur in de Indische mythölogie, heet de vrouw van Budha, (de planeet Mereurius). Zij komt ook voor als vrouw van Kaçyapa, van Wasudewa, van Rudra. Welken grond de dichter gehad heeft om Sanatkumāra, die met den krijgsgod Skanda vereenzelvigd wordt, met eene godin Iḍā te verbinden, outsuapt mij.

In de derde strofe leest men :

Těkwan wṛddhy awěkendra sang umunggw ing Wìrabhümy angḍiri | sang Çrì-Nāgarawarduhauì pratita rājūîkanyakānopama | ndan rantĕn haji rāja ratw ing Mataram lwir hyang Kumārāuurun | sang Çrì-Wikramawarddhaneçwara paningkah Çrì-narendhrādhipa || 3 ||

D. i. "Zij (d. i. Hayam Wuruk en zijne twee zusters) vermenigvuldigden zich, tot kinderen hebbende: 1) den vorst die te Wîrabhūmi keerschte; 2) de onvergelijkelijke kroomprinses bekend onder den naam vau H. Hoogh. Nāgarawardhanì ; dan (heeft) 's Konings zuster (van Lasĕm, tot zoon) den vorst van Mataram, die Kumāra (den

1 Misschien bedoeld: vast in den geloove, vroom. Doch het woord kan ook "betrouwbaar, trouw" beteekenen. 
Krijgsgod) op aarde neergedaald, leek, Z. Hoogh. Wikramawardhana, Regent Paningkah ${ }^{1}$ van den Oppervorst."

Zonder de hulp van de Pararaton zou de inhoud van deze strofe niet te verstaan zijn, want volstrekt noodige woorden om 't zinverband duidelijk te maken, ontbreken. Wij weten uit de Pararaton ${ }^{2}$, dat Hayam Wuruk een zoon en een dochter had, n.l. Bhre Wìrabhūmi en Bhre Lasěm. Deze nu vinden wij bij den dichter terug, die Z. Hoogh. van Wîrabhūmi 't eerste noemt, zonder te vermelden dat hij de zoon van een bijwijf was. De prinses heette Nāgarawarddhanì. Daarop worlt gesproken van den zoon van een der jongere zusters van Hayam Wuruk, en wel van H. Hoogh. van Lasĕm, gehuwd met den vorst van Matahun, want in de volgende strofe wordt van H. Hoogh. van Pajang gesproken. Deze prius, hier Wikramawardhana genoemd, heet korter Wikrama in Pararaton, 135. ${ }^{3}$ Dit maakt geen verschil; wel wijkt 't bericht in de kroniek in zooverre af, dat daarin Wikrama de zoon heet van van H. Hoogh. te Pajang, terwijl volgens den dichter haar zuster zijn moeder was. In dit geval mogen wij onbepaald 't gezag van Prapañca stellen boven dat van de Pararaton, aangezien hij een tijdgenoot was van de door hem genoemde personen.

De ligging van de stad of 't gewest Wirabhūmi is nog niet opgespoord.

In de vierde strofe leest men:

Wungsu Crì̀-nṛpatì Pajang siniwi munggw ing Pawwanawwan purì | rājn̄ì Çrì-Surawarddhanî̀ nwam ira wāla lwir, Hajĕng ning tulis | sakweh Çrì-Yawarāja sapaḍa madudwan nagarātunggalan | ekasthāna ri Wilwatikta mangisapwì sang narendrādhipa \|4 $\|$

D. i. "De jongste, H. Hoogh. de vorstin van Pajang, die regeert in de stad Pawwanawwan, haar jonge spruit was de vorstin H. Hoogh. Surawardhanì, die de (godin der) schoonheid op een schilderij geleek. Al de vorsten van Java hadden ieder een verschillende hoofdstad (met gebied), (maar) op één plaats, Majapahit. veegden zij de voeten van den Opperkoning."

De prinses Surawardhanì is dus de dochter van H. Hoogh. van

1 D. i. hij was gemachtigd van wege den Koning om te fungeeren als opperrechter; zie beneden VII, 4.

2 Blz. 135.

3 Evenzoo vindt men de naamvormen Harṣa en Harșawardhana van den beroemden Koning van Kanauj die in de eerste helft der $7^{\text {de }}$ eeuw regeerde, toen de Chineesche pelgrim Hiuen Thsung Indië bezocht. 
Pajang, wier gemaal Singhawardhana van Paguhan was. Dewijl Pahwanahwan uitdrukkelijk als hoofdstad genoemd wordt, zal Pajang de naam zijn van 't distrikt of regentschap. Niettegenstaande de weidsche titels, is het duidelijk, dat die "vorsten", uitgezonderd den heerscher te Majapahit, geen koningen wàren in den zin van Lat. reges, maar van "regenten". Welke stad Pawwanawwan is, blijft te onderzoeken. In de Pararaton komt de naam niet voor.

\section{Zang VII.}

De mant hiervan is de zgn. Jagaddhita. De eerste strofe luidt: Warṇnan Çrì-naranātha kastawan ira'n dinakarasama digjaya prabhu | bhrașta ng çatru bangun tamisra sahane bhuwana rinawasan ${ }^{1}$ nareçwara

tușțāng sajjana pangkajāmam ${ }^{2}$ ikanang kujana kumuda satya sātwika |

sthity ang grāma sabhūmy aweh dhana bangun jala hinaturakĕnya sakrama $\|1\|$

D. i. "Wij zullen den lof verkondigen van Z. Maj. den Koning, die der Zon gelijk een de wereld veroverend (en : de windstreken innemend) heerscher is. De vijauden zijn ten onder gebracht als de duisternis en alles wat er op de wereld is, heeft hij overmeesterd. Opgetogen zijn de goeden : (als 't ware) de waterrozen (die bij zonlicht ontluiken); de boozen vertoonen hun aanzicht niet: (als 't ware) de Nymphaca's (die zich bij zonlicht sluiten); in oprechte waarheid (mag men dit beweren). Trouw leveren de landgemeenten over 't geheele land belasting; als water wordt het door hen angeboden naar behooren."

Lwir sang hyang Çatamanyu manghudani rāt haji tumulaki duhka ning prajā

lwir hyang Piț̣pati kaḍaṇḍan jng anāryya Baruṇa ri katěmwan ing dhana |

lwir hyang Bāyu sirāntameng sakalaloka makaçaraṇa dūta nityaça |

lwir Pṛthwì ri karakṣan ing pura katonan ira kadi Bhațāra Candramā $\|2\|$

D. i. "Gelijk de god Çatamanyu (Indra) op de aarde regen geeft, weert de Vorst de armoede der onderdanen af. Gelijk de Heer der

1 Slechte spelling voor rinabhasan.

2 Zoo leze men voor 't onmogelijke panga van den tekst. 
Voorouders (Yama) straft hij de slechten; een Waruna als plaats waar men schatten vindt ${ }^{1}$; als god Wāyu (Wind) dringt hij in de geheele wereld door met steeds van spionnen gebruik te maken; als de Aardgodin (beschermgodin des lands) beschermt hij de stad; in voorkomen is hij als de Mangod."

De beschrijving van 's Konings voortreffelijkheden wordt nog voortgezet in de $3^{\text {de }}$ strofe:

Ring warṇṇākṛti Kāmadewa sakalānurun umulati rāmya ning purì| sakweh sang paraputrikādika wadhū haji.kadi pawibhajyan ing Ratih | ndan sang Çrì-Parameçwarì swaduhitā ṇ̣pati Wijayarājasottama |

mukyāwarṇna Susumnadewy anupameng hayu tuhu sawawe nareçwara \| 3 ॥

D. i. "Naar 't uiterlijk heeft hij de gedaante van Kāmadewa (den Minnegod), in levenden lijve nedergedaald om de bekoorlijkheden van den hofburg te aanschouwen. Al de prinsessen, euz., vrouwen des Konings, zijn als deelen van Rati ${ }^{2}$, (de gemalin van den Minnegod). H. Maj. de Oppervorstin ${ }^{3}$, dochter van den voortreffelijken vorst Wijayarājasa, de voornaamste, gelijk aan de Dewī van Susumna, onvergelijkelijk in schoonheid, is in waarheid den Koning waardig."

Ook uit de Pararaton weten wij, dat Hayam Wuruk tot Kouingin had de dochter van Wijayarājasa, anders getiteld Z. Hoogh. van Wěngkĕr, die getrouwd was met H. Hoogh. van Daha. De titel Paramaçori in Pararaton ${ }^{4}$ is slechts een jongere vorm van Parameçwari in bovenstaande strofe. Het is niet geheel duidelijk wie met de Dewì van Susumna (juister Suṣumna) bedoeld is; daar Suṣumua o. a. zounestraal beteekent, en Hayam Wuruk met de Zon vergeleken wordt, is de Dewì van Suṣumna beschouwd als de vrouw van deu Zonnegod.

Het is opmerkelijk, dat de dichter niet gewangt van 's Konings eerste vrouw, eene prinses van Suṇ̦a, die hij echter door den dood verloor, zooals men weet uit het bericht van de kroniek. Het stilzwijgen van den dichter over die eerste gemalin laat zich evenwel gereedelijk verklaren, omdat Prapañca den toestand beschrijft ten tijde toen hij zijn gedicht schreef. Dit kwam uit in 1365. Daar Hayam Wuruk reeds een getrouwde dochter had, kan het ge-

1 Omdat de Oceaan schatten in zijn schoot bergt.

2 Letterlijk: als 't ware plaatsen waar Rati zich verdeeld had.

$s$ D. i. de voornaamste gemalin, in 't Skr. gewoonlijk Mahișī betiteld.

4 Parar. blz. 143. 
boortejaar 1334, opgegeven in den eersten Zang, niet juist zijn. In de $4^{\text {de }}$ strofe maakt de dichter ons bekend met de dochter van 't koninklijk paar en haar huwelijk.

Těkwan wṛddhi sirān pakānak i sirang nṛpati Kusumawarddhanīçrarì |

rājūī rājakumāryy anindya siniwīng purā ring Kabalan uttameng raras |

sang Çrì-Wikramawarddhanendra saniruktya nira pangucap ing sanāgara |

sākṣāt dewata dewatì sira n-atěmu ahĕlĕm anukani twas ing jagat \| 4 \|

D. i. "En zij vermenigvuldigden zich door tot kind te hebben de vorstin Kusumawarddhanīçwari, de onberispelijke kroonprinses, die heerscht in de stad Kabalan, uitcrmate liefelijk; (en als schoonzoon) Z. Hoogh. Wikramawardhana, aan wiens uitspraak de rechtszaken van 't gehecle rijk onderworpen zijn. Als een mannelijke en vrouwelijke godheid zijn (deze twee) later getrouwd, tot vreugde van 't land."

Wikramawardhana, of zooals de Pararaton hem noemt: Haji Ratu Wikrama, wordt als schoonzoon van Hayam Wuruk ook in de kroniek vermeld. Uit de bewoordingen van 't dichtwerk blijkt, dat hij als hoofd der rechtspraak was auugesteld. Men zou hem dus waarnemend opperrechter kuunen noemen, want volgens Indisch recht is de Koning opperrechter van rechtswege. Het ambt van Wikramawardhana is oogenschijnlijk te vergelijken met dat van den Wĕdåuå Djakså te Solo, hoewel zijn gezag zich over een veel grooter gebied uitstrekte. Uit de Pararaton, blz. 14.9, leeren wij dat hij na den dood van zijn schoonvader in Çaka 1311 (1389 A. D.) dien in de regecring opvolgde: een zijdelingsch bewijs, dat de prins -Wîrabhūmi een onechte zoon van Hayam. Wuruk was. Anders zou hij, en niet de man van de echte dochter, tot de opvolging gerechtigd geweest zijn.

Kabalan komt in de kroniek mecrmalen voor, doch alleen in de verbinding Bhre Kabalan. ${ }^{1}$

\section{VIII.}

In dezen Zaug geeft de dichter cen beschrijving van de hoofdstad Majapahit. Deels ten gevolge van de bedorven lezingen, deels

1 Zie Register van Eigennamen, bl. 246. 
uit andere oorzaken, levert de vertaling veel moeielijkheden op en blijft er veel over wat nadere studie vereischt. Toch heb ik gemeend dat een vertaling, bij alle gebreken, belangstellenden welkom zal wezen.

De eerste strofe van dezen Zang, in een soort van Abhikṛtimaat, luidt aldus :

Warṇnan tingkah ikang parādbhuta kuṭanya bata-bang umidĕr mmakanděl aruhur |

kulwan dik purawaktra ${ }^{1}$ mangharĕpakĕn lěbuh agĕng $\mathrm{i}$ tĕngah way edran adalěm |

bhrahmasthāna matunggalan pathani buddhi jajar inapi kapwa sök caracara |

ngkā touggwan paratạ̣ḍa tanpĕgat aganti kumĕmiti karakṣan ing purasabhā || $1 \|$

D. i. "Wij zullen 't voorkomen beschrijven van al de wonderen (der hoofdstad): de ringmuur van rooden baksteen, dik en hoog; de ingang van de stad aan den Oostkant heeft vóór zich 't Plein ${ }^{2}$; binnen een diep water er om heen ${ }^{3}$; Brahmasthāna-boonen, ieder met een Bodhi-terras aan den voet, rijen vormende die alle dicht en van verschillende hoogte (?) zijn. Daar zijn geposteerd de beambten die onafgebroken om beurten waken voor 't policie-toezicht op de Paseban."

Als boomnaam wordt "brahmasthāna" verklaard als zijnde de Indische moerbezieboom. Ik roed eenigen twijfel of die soort boom hier bedoeld is, en zou eerder meenen dat vau Açwatthas (Ficus religiosa) sprake is, en wel omdat bij die boomen Bodhi-terrassen, of zooals ze in 't Pāli en Buddhistisch Sauskrit heeten : Bodhimaṇḍa's, zeer gewoon zijn. ${ }^{4}$ Caracara is in Zang XI, 2 en XXXIII, 1 "allerlei" : wat hier juist bedoeld wordt, is niet duidelijk.

De beschrijving gaat in de tweede strofe aldus voort: Lor ttang gopura çobhitābhinawa kontĕn ika wĕsi rinūpakāparimita | wetan saṇḍing ikārjja panggung aruhur patiga nika binajralepa maputih

1 Conjectuur voor 't zinledige dhidw urå van den tekst.

2 Met andere woorden: als men van 't Oosten de stad binnenkomt, heeft men vóór zich.

3 Dit kan toch niet slaan op het plein. De gedachtengang laat zich, dunkt mij, aldus anders uitdrukken: De ringmuur enz., aan welks oostelijken ingang binnenkomende men een plein v5ór zich ziet, is omgeven door een diepe gracht."

4 Ook is op te merken dat "brahmakșetra", in MBh. XIV, 44, 11 op hetzelfde neêrkomende als "brahmasthāna" synoniem is van "plakṣa", een benaming zoowel van de Ficus infectoria, als de Ficus religiosa. 
kānuah ' lor-kkidul i pěkĕn rakět ikang yaça wĕkas ing apañjāng adbhuta dahat

angkĕn Caitra pahöman ing balasamūha kidul ikā catuṣpathāhyang ahalĕp || 2 \|

D. i. "Ten Noorden de prachtige, wonderfraaie hoofdpoort, welker ijzeren deuren met tallooze figuren versierd zijn. Naast de Oostzijde prijkt een hooge koepel, waarvau de vloer met wit (zgn.) diamantcement belegd is. Van Noord naar Zuid ligt het marktplein, met dicht aaneenstaande gebouwen, uitermate lang, zeer wonderschoon; iedere maaud Caitra komt 't vergaderde heir daar raadhouden; ten Zuiden (is) cen mooie viersprong".

Ahyang en ahalĕp worden als synoniem beschouwd; daarom heb ik ter vertaling maar één woord gebruikt. Eigenlijk beantwoordt ahyang geheel aan 't Fransche "divin", want het is afgeleid uit "hyang", godheid; evenals "divin" gaat het over in den zin van zeer schoon en dgl.

Omtrent de groote vergadering, welke jaarlijks in de maand Caitra (April) gehouden werd, zijn wij van elders niet ingelicht. Aan de hoven te Solo en Jogyakarta zijn er misschien overleveringen bekend over een samenkomst ter hoofdplaats van de gewapende macht.

Verder lezen wij :

Alwāgimbar ikang wanguntur i caturddiçi ${ }^{2}$ watangan ikā witāna ri těngah |

lor ttang weçina panangkilan parabhujangga kimuta paramantry alěnggih apupul |

wetan nggwan para-Çaiwa-Boddha mawiwāda mucap aji sahopakāra wĕki sök |

prāyaçcitta ri kāla ning grahaṇa Phalguṇa makaphala haywa ning sabhuwana \| 3 \|

D. i. "Ruim ${ }^{3}$ is de Manguntur met aan de vier windstreken het toernooiveld en een overdekte koepel in 't midden. Ten Noorden de audientiezaal, waar de geleerden en koninklijke raadslieden (ministers) te gader zitten. Ten Oosten is de plaats waar de Çiwaietische en Buddhistische geestelijken bij 't disputeeren spreken over de leer, mitsgaders overvloedige benoodigdheden, voor zoenoffers ten tijde van een eklips (terwijl de Maan) in 't sterrebeeld Phalguna (staat), welke 't heil van 't gansche land ten gevolge moeten hebben."

1 Kānnah voor kaĕnah, doch het juiste zal wel kārṇnah zijn.

2 In den tekst: an hatur, reeds metrisch onmogelijk.

$s$ Het verdachte en in alle geval onbekende woord (a)g imbar onvertaald. 
Waarom hicr juist van een eklips bij 't sterrebecld Phalguna ${ }^{1}$ gesproken wordt, is niet duidelijk. Zulk een eklips komt toch niet gedurig voor. In de Bṛhat-Samhitā van Warāha-Mihira, V, 73, wordt wel opgegeven welke volken en klassen van menschen kwaad te duchten hebben bij een maansverduistering in de maand Phālguna, maar in elke maand zijn van een eklips kwade gevolgen te duchten.

$\mathrm{Nu}$ de $4^{\text {de }}$ strofe :

Kānnah wetan ikang pahoman ajajar ttigatiga ri tĕngah kaçaiwan aruhur |

nggwan sang wipra kidul paḍottamasusun barat,i natar ikābatur patawuran |

nggwan sang Sogata lor susun tiga tikang wangunan i pucak ārjja mokirukiran |

kapwāñjrah racananya puṣpa pinaran ṇ̣pati satata yau hinoma ${ }^{2}$ mapupul || $4 \|$

D. i. "In 't Westen bevinden zich de vuurofferplaatsen in rijen drie aan drie; in 't midden een hooge Cliwaietische tempel. Ten Zuiden de verblijven der Brahmanen, alle zeer hoog van verdiepingen; ten Zuidwesten hun voorplein met de verhevenheid waar de offeranden verricht worden. De verblijven der Buddhistische geestelijken ten Noorden, met dric verdiepingen van bouw; de spitsen fraai met veel beeldhouwwerk. Dat alles is met bloemcu in menigte bcstrooid wanneer de Koning daar komt, telkens bij een gezamenlijke offerplechtigheid."

Uit de bewoordingen van den laatsten regel zou men geneigd zijn op te maken dat bij bepaalde gelegenheden Çaiwa's en Saugata's gezamenlijk een godsdienstige plechtigheid vierden, welke door Z. Majesteit werd bijgewooud. Dit heeft bij de bekende vriendschappelijke verhouding der sekten en 't latitudanarisme der heerschers niets bevreemdends.

De vijfde strofe luidt als volgt:

Ngkāneng jro kidul ing wanguntur ahĕlĕt palawangan ikana pasewan atatā

weçmārjjājajar anghapit hawan angulwan i tĕngah ika tañjung angjrah asěkar |

ndah kulwan mahělĕt muwah kidul i panggung ika bala maneka ${ }^{3}$ medran i těpi |

1 D. i. als de volle maan in dat sterrebeeld staat.

2 De tekst heeft een onmogelijk hanoma.

${ }^{3}$ Conjectuur voor yaneka. 
ardđhālwā ri těngah natar nikana maṇḍapa pasatau asangkya lot mawurahan $\|5\|$

D. i. "Daar binnen, Zuid van de Manguntur, op eenigen afstand (is) de galerij, de gewone plaats der audienties. ${ }^{1}$ Fraaie gebouwen op een rij aan beide kanten van den $r e g$, die naar 't Westen loopt; te midden daarvau overal blociende. Mimusops. En ten Westen, wederom op eenigen afstand zuidelijk, de hooge koepel waar veel volk (of: krijgers) aan den kant om heen zich beweegt. Zeer ruim, in 't midden van 't voorplein, is een paviljoen waarin ontelbare onophoudelijk luidruchtige vogels ziju."

$\mathrm{Nu}$ ten slotte:

Ri jronyeki muwah pasewan i ${ }^{2}$ kidul dudug angusi wijil kapingrwa ri dalĕm |

tingkahnyeki tinumpatumpa mahĕlět palawaugan ikanang sapaṇṭa tinika $^{3}$ |

kapwāug weçma 4 subaddha watwan ika len saka balabag usuknya tanpacacadan |

sěk de ning bala hajy anangkil agilir makĕmit anu mapekșa wāra matutur || 6 ||

D. i. "Hier binnen wederom een audientiehal in 't Zuiden, die doorloopt tot den tweeden uitgang ten paleize. Deze ${ }^{5}$ zijn zoo geordend, dat ze opeengehoopt (staan); al de zoo geordende groepen hebben een galerij in de tusscheuruinte. De gebouwen hebben stevige omlijstingen en pilaren; de planken en ribben ervan zijn zonder gebreken. In menigte maken de dienaren des konings in geregelde afwisseling hun opwachting, de wacht houdende, in afwachting van de volgende beurt."

IX.

Deze Zang, in Sragdharā-maat, bevat ettelijke uitdrukkingen, waarbij de bestaande hulpmiddelen ons in den steek laten. Doch al is niet alles duidelijk, er blijft genoeg over, warmede wij hier kennis maken. De eerste strofe geeft ons 't volgende te lezen :

1 Palawangan vertaal ik zoo, naar anclogie van Fransch "portique". In geen geval past de hedendaagsche beteekenis.

2 De tekst heeft akidul.

3 Conjectuur voor 't metrisch onmogelijke tiningkah van den tekst.

4 In den tekst kapwaw we çma.

${ }^{5}$ Het is niet overduidelijk waarop dit woord slaat; denkelijk op de roornoemde gebouwen. 
Nāhan lwirnyang manangkil pangalasan i ngaran kwehnya tanpapramāṇa |

tanpalwir ny ū-gaḍing Janggala Kaḍiri sĕḍah panglarang rājadewī| wai-çangkā (?) wwang paneww an kṛtapura sinělir mwang jayeng prang jayāgöng |

angreyok kayw apu wwang jaladhi masuruhan sāmajādhi prakìrṇna $\|1\|$

D. i. "Op die ${ }^{1}$ wijze maken zij hun opwachting. De zoogenoemde Pangalasans, wier menigte ontelbaar is, (bieden aan) ${ }^{2}$ onvergelijkelijke ivoorkokosnoten van Djanggala en Kaḍiri, en betel tot privaatgebruik der koningsvrouw (of: vrouwen); Panewu's, die wegens vroegere verdiensten in gunst staan en overwinnaars in den oorlog, groote helden, Çankha-schelpen (?); zeelieden, kroos in de handen wringende (?), bieden als hun bijdrage voortreffelijke bronstige olifanten."

Met Pangalasans schijnen zekere beambten in de bosch-distrikten bedoeld te zijn; zij komen blijkbaar hier uit Djanggala en Kaḍiri en bieden de voortbrengselen uit hun streek aan, voortbrengselen welke daar, naar het schijnt, bijzonder goed zijn.

Met wai-çangkā weet ik niet recht weg. De lange " $\bar{a} "$ zal wel een fout wezen. Wai is water; çangka, d.i. Skr. çangkha, de schelp Turbinella rapa. De samenstelling "waterschelp" is toch eenigszins vreemd en men begrijpt niet waarom juist Panewu's hiermede aankomen. Intusschen wordt aan deze soort schelpeu groote waarde gehecht en makt men er allerlei voorwerpen uit; ook wordt ze gebruikt als bazuin. De zeevaarders bieden olifanten aan, die zij uit vreemde landen, Indië of Sumatra, anvoeren ; op Java komen, zooals men weet, geen olifanten in wilden staat voor. Het eigenaardige van de handeling, welke met angreyok kayw apu wordt aangeduid, blijft mij verborgen, ook omdat de woordenboeken ten opzichte der beteekenis van 't werkwoord onbetrouwbaar, of ten minste onvoldoende zijn.

De tweede strofe luidt als volgt:

Nāhan ${ }^{3}$ tādhinya munggw ing watangan alunalun tanpĕgat lot maganti |

1 Men zou eer verwaehten „op deze (volgende) wijzc", doch er staat bepaald $\mathrm{na} h \mathrm{hn}$, wat op 't voorafgaande wijst, niet nihan.

2 Zulk een woord moet men in gedachte aanvullen.

3 Wederom $n \bar{a} h$ an, dat wegens 't volgende tā dhinya, de voornaamsten, niet past. Doch dit kan een slordige spelling zijn van tādinya, de eersten. 
tanḍa mwang gusti wadwā haji muwah ikang amwang tuhan ring Yawābāp |

mukya'ng munggw ing wijil pingkalih adhikabhayangkāryy apintāpupul sök |

lor ning dwāre dalĕm nggwanya kidul ika parakșatriya mwang bhujangga || 2 \|

D. i. "Zoo dan zijn de voornaamsten ${ }^{1}$ in de Paseban op de Alun-alun zonder ophouden voortdurend afwisselend; officieren en annvoerders der koninklijke troepen en die den Heer van Java troepsgewijs bewaken; de voornaamsten, die aan den tweeden uitgang, uiterst vrees inboezemende, in menigte afzonderlijk bijeengeschaard, hebben hun plaats ten Noorden van de paleispoort; ten Zuiden de Kșatriya's en geleerden."

Verder leest men :

Ngkāneng bāyabya ri paçcima midĕr umāreng Mṛtyudeça yaçākweh | sarsök de sang sumantry amawa pinituha ring wìrabhṛtyān panangkil | anyat kannah kidul pāntaran ika lawangan manḍapa mwang gṛhākweh | sarsök de bhṛtya sang Çrì-nṛpati ri Paguhan nityakāla'n pasewa || 3 ||

D. i. "In 't Noordwest ten Westen, rondgaande tot aan 't Zuiden zijn veel gebouwen, vol bezet door de Mantri's in functie ${ }^{2}$, de Seniores (hoogsten in rang) onder de dienaren van den Held (d. i. de Vorst), die hun opwachting makeu. Anderen hebben hun plaats Zuid, op eenigen afstand ervan portieken (?), Pĕndopo's en huizen, in menigte, stikvol van dienaren van Z. Hoogheid den vorst van Paguhan, die te allen tijde hun opwachting maken."

$\mathrm{Nu}$ de laatste strofe :

Ngkāne jro ning wijil pingkalih arĕja natarnyāratālwātiçobha | sök weçma mwang witānābhinawa mapupulan ${ }^{3}$ sang manangkil mareng jro |

wetan tekang gṛhānopama wangunan ikāçry āruhur sopacāra | nggwau Çrì-Nātha'n paweh sewa ring umarĕk umungg w ing witānāprameya || $4 \|$

D. i. "Binnen den tweeden uitgang prijkt het effen, ruime, zeer schoone voorplein, (met) veel gebouwen en verrukkelijk mooie overdekte zitplaatsen ${ }^{4}$; (hier) verzamelen zich degenen die naar binnen

\footnotetext{
1 Of men leze tā dinya, de eersten.

2 Deze vertolking van a maw a is slechts een gissing.

3 Foutief in den tekst papupulan.

"Dit moet hier bedoeld zijn; dus z. v. a. "bangsal witāna", en niet verhemelte alleen.
} 
hun opwachting gaan maken. Oostelijk is 't gebouw van weergaloozen bouwtrant, prachtig, hoog, met sieraden, waar Z. Maj. de Vorst, audientie geeft, in 't onvergelijkelijke overdekte paviljoen, aan degenen die eerbiedig naderen."

$\mathrm{X}$.

Deze Zang bestaat grooteudeels uit een opsomming van personen, die cen of andere wardigheid bekleeden. Verscheidene van die titels zijn op Java nog in gebruik of althans bekend, zoodat ik ze niet door Nederlaudsche termen vervangeu heb, voor welke laatste wij trouwens geen gelijkwardige uitdrukkingen bezitten. Eenige wardig. heden zijn thans niet meer bekend, en daar de woordenboeken geen hulp boden, heb ik mij mcer dan mij lief is, met gissingen moeten behelpen.

Wat de rerzen anngaat, deze behooren tot de klasse Dhṛti; de bijzondere naam is onbekend. De mat heeft groote overeenkomst met het Harinapluta, in een Indisch werk over verskunst vermeld, maar is toch niet geheel gelijk. Ze heeft, evenals nog andere Oudjavaansche maten, het voorkomen van sanengesteld te ziju uit de eerste twaalf voeten van Çārdūlawikrídita tot aan de caesuur, vermeerderd met een verlengstuk. Hetzelfde karakter heeft de maat van Zang VIII, die in Oudjavaausche gedichten meermalen wordt aangetroffen. Doch 't verlengstuk is daar langer dan in VIII.

De eerste strofe geeft het volgende te lezen :

Warṇnan warṇna ni sang manangkil irikang witāna satata| mantri wṛ̣ddha parāryya len parapasangguhan sakaparĕk | mwang sang pañca ri Wilwatikła mapagĕh dĕmung kanuruhan | tansah rangga tumĕnggung uttama ni sang marěk wěki pěnuh $\| 1$ |

D. i. "Wij zullen de hoedanigheid beschrijven van hen die geregeld in de Bangsal Witana hun opwachting maken: de Mantri Sĕpuh, de Ārya's en de Pasangguhans ${ }^{1}$ van den eersten rang; en de vertrouwde Vijfmanuen van Wilwatikta (Majapahit), de Dĕmungs, Kanuruhans ; onmiddellijk daarop volgen de Raugga's, Tumĕngguings, (dat) zijn de hoogsten die in grooten getale den troon naderen."

In de tweede strofe gaat het aldus voort: Kweh ning weça purì kamantryau ing annātya ring sauāgara |

\footnotetext{
1 Welke voorname waardigheidsbeklesders dezen titel dragen, kan ik niet eens raden.
} 
don iug bhāṣa parāpatih paraděnung sakala n-apupul | anghing saug juru ning watĕk pangalasan mahìngan apagĕh | pañca kweh nira mantry anindita rumakṣa kāryya ri dalěm $\| 2$ |

Hierin is veel raadselachtigs. Voorcerst stuiten we op weça purí. De gewoue beteckenis van weça (Skr. betere spelling: weșa) is "klecdij, kostuum". Ik vermoed dat "weça purì" een elliptische uitdrukking is voor iemand die met een ambt bekleed is. Voorts is het zinverband zeer onduidelijk. Niet dan gissenderwijze en onder alle voorbehoud, geef ik van de strofe deze vertaling:

"De menigte van beambten van 't hof vau de Kamantrèus der koninklijke raden in de geheele stad, de Patihs en de Děmungs, alle die zich verzameld hebben, zijv er met doel om hun woord te doen $^{1}$; slechts ${ }^{2}$ de hoofden van de schare der Pangalasaus bewijzen trouw te zijn. Vijf is 't aantal der Mantri's zonder blaam, die op de aangelegeuheden in 't paleis passen."

In de eerste strofe was er sprake van de Vijfmannen in de hoofdstad. Kwalijk zijn deze te vereenzelvigen met de vijf Mantri's in den vierden regel.

Dĕmung is als titel van een voornaam beambte in vroeger tijd nog op Java bekend. Vgl. Kawi-Bal. Wdb. van v. d. Tuuk, D. II, 526 .

Kanuruhan uit Oudjav. geschriften bekend; een bijvorm is "kandururuhan", in 't Maleisch overgenomen.

De derde strofe heeft:

Ndan sang kṣatriya len bhujangga rĕși wipra yapwan umarĕk | ngkāuc hčb ning açoka munggw i hiring ing witāua mangadĕg | dharmmādhyakșa kalih lawan sang upapatti saptādulur |

saug tuhw āryya lěkas nirān pangaran āryya yukti satirun || 3 ||

D. i. "En de Kṣatriya's en geleerden, Rși's ${ }^{3}$, brahmanen, wanneer zij den troon naderen, staan in de schaduw van den Açokaboom nast de Bangsal Witaua; de tivee voorzitters der rechtbauk en de zeven assessoren; zij, die in hun gedragingen in waarheid zoo edel (ārya) zijn, dat zij te recht navolgenswaardige Ārya's zijn."

1 De vertaling niet geheel zeker. Don ing bhāṣa, letterlijk: doel, van de (beleefde) taal.

2 Bedoeld, als ik het wel begrijp: alleen de hoofden, niet de geheele troep, betuigen onwankelbare trouw aan den Koning.

3 Dit woord is hier niet in den eigenlijken zin gebruikt; misschien z. v. a. groote geleerden, of als heiligen te vereeren personen. 


\section{XI.}

De maat van dezen Zang is van de klasse Wikṛti, en bestaat uit een verbinding van de eerste 12 voeten van 't Çārdūlawikríditametrum en een verlengstuk, evenals de maat van VIII en XI, maar 't aantal der toegevoegde voeten verschilt in de drie Zangen.

De eerste strofe luidt:

Nā lwir sang marěk ing witāua pinake dalěm inapi rinangga çobhita |

ring jro pūrwwa sake wijil pisan adoh piningit ikang umañjinge dalĕm |-

ndan sang Çrî̀-ı̣pati Singhawarddhana kidul saha yugala saputraputrikā |

lor sang Çrì-Kṛtawarddhaneçwara baugun surapada tiga tang purāpupul || 1 ||

D. i. "Zoodanig zijn degenen die den troon naderen in de Bangsal Witana, bestemd voor den Vorst, fraai gevormd en versierd, van binneu. Zuidelijk van den.eersten uitgang, wordt op zekeren afstand verboden 't hof binnen te gaan. ${ }^{1}$ Dan in 't Zuiden is ('t verblijf van) Z. Hoogh. Singhawarddhana met zijn gade, zoon en dochter; Noordelijk is ('t verblijf vau) Z. Hoogh. Kṛtawardhaneçwara. De drie paleizen te zamen lijken Hemelwoningen,"

Z. Hoogh. Singhawardhana hebben wij in Zang VI leeren keunen als den gemaal van H. Hoogh. van Pajang en zelf Heer van Paguhan. Kịtawardhaneçwara is de vader van Hayam Wuruk en de man van $H$. Hoogh. van Kahuripan.

De tweede strofe bevat een beschrijving van de schoouheid der gebouwen.

Sakweh ning gṛha nora taupasaka mokirukirau apěnĕd winarṇ̣̣ana | mwang tekang batur açmawișțaka ${ }^{2}$ mirah winětuwinětu pinik rinūpaka |

ñjrah tekang wijil ing kulāla piuakottama ni hatěp ikang gṛhādhika | tañjung keçara campakādi nikang kusuma caracarāñjrah ing natar || 2 \|

D. i. "Al de huizen zijn voorzien van zuilen met beeldhouwwerk,

1 D. i. als ik het wel begrijp: is er een ruimte die onbevoegden niet mogen betreden om 't paleis binnen te gaan.

2 Een fout, hetzij van een afschrijver of van den dichter zelven, voor ișțaka Dit kan er oorspronkelijk evenwzl niet gestaan hebben; mogelijk een onjuist gespeld hișțaka, Skr. iṣțakā. 
sierlijk geschilderd, en de Batur van rooden baksteen is -1 met figuren; overal ziet men de voortbrengselen van pottenbakkers dienende voor de toppen van de daken der voorname huizen. Mimusopsbloemen, Keçara's ${ }^{2}$, Campaka's en andere bloemen van allerlei soort zijn overal verspreid op het voorplein."

\section{XII.}

Deze Zang, in Çārdūlawikriḍita-maat bevat een beschrijving, of liever een opsomming, van woningen van aanzienlijken in de stad. Warṇnan tingkah ikang pikanděl atatā tūt kaṇța ning nāgara | wetan sang dwija Çaiwa mukya sira ḍang hyang Brahmarājādhika | ngkāneng dakṣiṇa Boddha mukya ng anawung sang kāka Rĕngkannadì | kulwan kṣatriya mantri punggawa sagotra Çrì-narendrādhipa $\|1\|$

D. i. "Wij zullen deu staat beschrijven vau de omgeving langs de zijden van de stad. Oostelijk (wonen) de Çiwaietische brahmanen, van wie de Hoogeerwaarde Brahmarāja ${ }^{3}$ de vooruaamste is; in 't Zuideu de Buddhisten; de voornaamste van den Sangha (Congregatie) is de Sthawira ${ }^{4}$ Rĕngkannadi ${ }^{5}$; Westelijk de Kșatriya's, Mantri's, Punggawa's en verwanten van Z. Maj. den Soeverein."

In de tweede strofe gaat het aldus voort:

Wetan (n)dan mahĕlĕt lěbuh pura narendreng Wĕngkĕr atyadbhuta | sākṣāt lndra lawan Çacì nụpati lāwan sang narendreng Daha |

sang nātheng Matuhan narendra ri Lasěm munggw ing dalĕm tan kasah |

kannah dakṣiṇa tan madoh kaměgĕtan sang nātha çobhāhalĕp $\|2\|$

D. i. "Voorts ten Oosten met het Plein er tusschen is het wonderschoone paleis van den vorst van Wĕngkĕr; te vergelijken met Indra en Çacì is de(ze) vorst met de vorstin van Daha. De heerscher van Matahun (en) de vorstin van Lasĕm hebben hun plaats in 't onmiddellijk grenzende Hof; Zuidelijk, niet ver af, is gelegen de aanzienlijke huizing ${ }^{6}$, prachtig schoou, van den vorst."

1 De woorden winĕtuwĕtu pinik versta ik niet.

${ }^{2}$ Keçara is in 't Skr. benaming van verschillende bloemen: Rottleria, Mesua en Mimusops Elengi.

${ }^{3}$ Of, mogelijk, Brahmarājādhika. Doch van elders is alleen een naan als Brahmarāja bekend, zoodat adhika, voornaamste, hier een stoplap is. Is adhika een verkeerde spelling van ādika, dan luidt de vertaling: „Brahmarāja enz. de voornaamsten zijn".

4 D. i. Senior, dus eigenlijk hetzelfde als Presbyter.

5 Dezen zonderlingen naam weet ik niet te verklaren.

6 Kamĕgĕtan is "de woning van een aanzienlijke, notabele". 7e Volgr. IX. 
De vorst van Wĕngkĕr en zijne gemalin kenuen wij uit Zang IV en de Pararaton, als de angetrouwde Oom en eigen Tante van Hayam Wuruk. De vorst vau Matahun en zijne vrouw, vorstin van Lasĕm, zijn vermeld in Zang VI.

$\mathrm{Nu}$ de derde strofe :

Ngkāneng uttara lor sakeng pĕkĕn agöng kuww ahalěp çobhita| sang sākșāt ari de nareçwara ri Wĕngkěr sang makuww āpagěh | satyāsih ri narendra dhîra nipuneng nìty āpatih ring Daha | khyātìng rāt mangaran bhațāra narapaty angde halěp ning prajā || $3 \|$

D. i. "In 't Noorden, noord van de Groote Markt, is een allerfraaist verblijf; hij, die als een ware jongere broeder is vau den vorst van Wĕngkĕr, is degene die daar vast zijn intrek neemt: oprecht den Vorst genegen, moedig, knap in de staatkunde, als Patih van Daha, in den lande bekend onder den naam van Bhațāra Narapati, die 't heil des volks bevordert."

Voor kuw u hier wist ik geen geschikte uitdrukking ter vertaling. In 't bijzondere geval van den Patih van Daha, zou men geneigd zijn 't woord weer te geven met wat tegenwoordig in 't Javaansch heet Poudok, waut de Patih van Daha zal toch wel slechts tijdelijk in de rijkshoofdstad vertoefd hebben. Maar in de volgende strofe heet ook het verblijf van Gajah mada een $\mathrm{kuwu}$. De beste vertaling zal dus wel wezen 't Fransche "hôtel".

Over Gajah mada wordt in strofe 4t uitgeweid.

Wetan lor kuwu sang Gajah-mada patih ring Tiktawilwādhika| mantrî̀ wî̀ra wicakṣaṇeng naya matanggwau satya bhakty aprabhu | wāgmì wāk apadu sārjjawopasama dhîrotsāha ${ }^{1}$ tan lālana| rājādhyakṣa rumakșa ri sthiti narendrāu cakrawarttīng jagat || 4 ||

D. i. "Noordoost is het verblijf ran Gajahmada, Patih van Majapahit $^{2}$ : den Mantri dapper, wijs in beleid, betrouwbaar, oprecht onderdanig jegens den Koning, welsprekend in pleitrede, rechtschapen, bezadigd, standvastig, wakker, voortvarend, Rijksfiscaal, die zorg draagt voor (de handhaving der) verordeningen van den Koning als wereldbeheerscher."

De vijfde strophe luidt :

Nda ngkāne kidul ing purì kuwu kadharmmādhyakșan arddhāhalěp | wetan rakwa kaçaiwan uttama kaboddhan ${ }^{3}$ kulwan açry àtatā|

1 In den tekst foutief dhīhotsāha.

2 A dhika, superieur, is in de vertaling uitgelaten, daar niet duidelijk is of het op den persoon slaat of een nietszeggend epitheton is van Majapahit.

s In den tekst verkeerdelijk $\overline{\mathbf{a}}$ voor an. 
tan warṇnan kuwu sang sumantry adhika len sang parakṣatriya | de ning kweh nira bheda ri sakuwu ${ }^{1}$ kuww angde halěp ning pura || 5 ||

D. i. "En ten Zuirlen van 't paleis des Konings is het zeer schoone verblijf van den Dharmādhyakșa ${ }^{2}$; ten Oosten daarvan is een uitstekend Çiwaietisch heiligdom; ten Westen een prachtige Buddhistische tempel. Wij zullen niet beschrijven het verblijf van den voornanmsten Mantri en de Kșatriya's. De groote verscheidenheid in de verschillende verblijven is een sieraad van de stad."

De beschrijving van de hoofdstad wordt besloten met de volgende verzen :

Lwir ccandrāruṇa tekanang pura ri Tikta-çrìphalānopama | tejānggěh nikanang kara sakuwukuww akweh madudwan halěp | lwir ttārāgraha tekauang nāgara çeșa nneka ${ }^{3}$ mukya ng Daha | mwang uūṣāntara sarwwa maṇḍalika 4 rāṣțrāngāçrayāk weh marĕk || 6 ||

D. i. "Gelijk de Maan en de Zon is de onvergelijkelijke stad Tikta-çrîphala ${ }^{5}$; schitterend de plaats innemende van hun (der 'Zon en Maan) stralen, zijn de vele onderscheiden verblijven, die ieder hun verschillend schoon hebben. Gelijk planeten zijn de vele overige stedeu met Daha aan 't hoofd, en de andere eilanden, alle vasalstaten, welke in menigte steun zoekende hun opwachting maken."

Hiermede is de beschrijving van Majapahit, zooals het was in den tijd van Hayam Wuruk, ten einde. In de twee volgende Zangen geeft de dichter een opsomming van de wingewesten in den Indischen Archipel en op 't Maleische schiereiland, welke aan 't gezag van 't rijk van Majapahit onderworpen waren. Vermits van die Zangen reeds vroeger een vertaling verschenen is, welke tot belangrijke opmerkiugen van den Heer Rouffaer aanleiding heeft gegeven, kan ik hier volstaan met naar hetgeen over die buitenbezittingen van 't Javaansche rijk geschreven is, te verwijzen.

\section{Zang XV.}

$\mathrm{Na}$ in de twee voorgaande Zangen de onderhoorigheden van Majapahit opgesomd te hebben, vermeldt de dichter de landen

1 Zoo leze men instede van $\mathrm{tuw} u$ in den tekst.

2 D. i. Voorzitter van 't gerechtshof.

3 De verdubbeling dient om de voorgaande lettergreep lang te maken. $\mathrm{Om}$ de caesuur die achter șa valt niet in 't midden van een woord te doen vallen, heeft de dichter, denk ik, vermeden çesāneka te schrijven.

4 Zoo leze men voor maṇ duhalitā.

5 Çrīphala is een der vele namen van de vrucht van Aegle Marmelos, dus synoniem van wilwa (bilwa). Tikta-ęrīphale is een vertaling van Maja pahit, bittere Aegle-Marmelosvrucht. 
waarmede Hayam Wuruk vriendschappelijke betrekkingen onderhieId. Deze Zang in de maat Çikhariṇi begint in dezer voege :

Nahan lwir ning deçāntara kacaya de Çrì-narapati | tuhun tang Syang ngkāyodhyapura kimutang Dharmmanagarī|

Marutma mwang ring Rājapura nguniweh Singhanagarì |

ri Cāmpā Kāmbojānyat i Yawana mitreka satata \|l 1 \|

D. i. "Dat zijn de andere landen (dan Java), die door Z. Maj. den Opperkoning beschermd ${ }^{1}$ worden. Doch Siam, waar Ayodhyā (ligt), alsook Dharmanagarì, Martaban, Rājapura en Singhanagarì (d. i. Singapur), Campā, Kamboja en buitendien Yawana, dit zijn bestendige bondgenooten."

De gewone Oudjavaansche vorm van Siam zal wel Syan geweest zijn; de $\mathrm{ng}$ in Syang ten gevolge van de volgende gutturaal. Ayodhya $\bar{a}$ is welbekend nog heden ten dage in de verbasterde uitspraak Ayuthia of Yuthia. Volgens Siameesche berichten werd deze stad tot hoofdstad verheven door den koning Ramathibodi, anders genaamd Phra Utong, die in 1344 aan de regeering kwam en zijn rijk als veroveraar machtig uitbreidde. De ligging van Dharmanagarì is mij onbekend.

Marutma sluit zich aan bij Martaman, een ouderen vorm voor 't gewone Martaban; in de landstaal, het Talaing, heet de stad volgens $\mathrm{Hobson}-\mathrm{J}$ obson, ș. v. Martaban: Müttana n. Rājapura is de hoofdstad van Kalingga. Omtrent Yawana verkeeren wij in onzekerheid. Zooals men weet, is Yawana in ouderen tijd een benaming voor de Grieken, doch later na de opkomst van den Islām, hebben de Indiërs het woord toegepast op de Mohammedanen. Indien de Javaansche dichter hetzelfde spraakgebruik volgde, moet hij een Mohammedaansch rijk bedoeld hebben. Nu stond Bengalen en een groot gedeelte van Noordelijk Indië in 't midden van de $14^{\text {de }}$ eeuw onder een Mohammedaansch heerscher, namelijk Firuz Tughlak, koning van Delhi, die van $1351-1388$ regeerde. Hij was dus een tijdgenoot van Hayam Wuruk, en het is zeer wel mogelijk dat tusschen beide vorsten vriendschappelijke betrekkingen bestonden.

In de tweede strofe wordt over Madura gesproken en dienaangaande een zeer merkwaardige bijzonderheid medegedeeld.

Kunang tekang bhūmî Madhura tatani lwir parapurì|

ri denyān tunggal mwang Yawadharaṇi rakwekana danḡ

1 Eigenlijk: onder zijne beschermende schaduw staande. Caya is Skr. chāyā, waarvan de beteekenis pālana, bescherming, in inheemsche bronnen wordt opgegeven. 
samudrāuanggung-bhūmi kěta Çakakālanya karěngö |

těwĕknya'n dady āpāntara sasiki tatwanya tan adoh || 2 ||

D. i. "Wat aangaat het land Madura, dit is niet te beschouwen als een vreemde staat, om reden het in 't verleden één was met 't land Java: naar luid der overlevering namelijk was 't Çakajaar $4-1$, het tijdstip dat het een op zichzelf staand (eiland) werd op eenigen, niet verren afstand."

De waarde van de hier medegedeelde overlevering kunnen wij nict beoordeelen: het ontbreekt ons daarvoor aan alle gegevens. Maar verrassend blijft het, dat men in den tijd des dichters kennis droeg of ten minste meende te dragen van een gebeurtenis ongeveer acht eeuwen vroeger voorgevallen. In 't jaarcijfer is de waarde van het tiental onzeker, doch 't eeuwcijfer 4, en dit is 't voornaamste, staat vast. Ook weten wij met zekerheid, dat Java reeds in 't begin der $5^{\text {de }}$ eeuw geheel onder Indischen invloed stond, zoodat er in de opteekening van zulk een belangrijke gebeurtenis als de afscheuring vau Madura niets onwaarschijnlijks ligt.

De $3^{\text {de }}$ strofe heeft betrekking op de cijus door de onderhoorige eilanden aan den Soeverein.

Huwus rabdha ng dwīpāntara sumiwi ri Crì-narapati |

paḍāsthity awwat pāhudhama (?) wijil angkĕn pratimasa

sake kotsāhan sang prabhu ri sakahaywanya n-iniwö|

bhujangga mwang mantrīnutus umahalotpatti satata || 3 ||

D. i. "Nadat de audere eilanden Z. Maj. den Vorst gehuldigd hadden, brachten zij stipt de op elken termijn verschijnende cijns. ' Wegens 't streven van den Vorst om de (algemeene) welvaart te bevorderen, werden Bhujangga's en Mantri's uitgezonden om geregeld de opbrengst te innen."

De Bhujangga's zijn geleerden en geestelijken; een geschikt equivalent in 't Middelnederlandsch is 't woord "clerk". De Mantri's hier bedoeld, zijn blijkbaar ambtenaren van 't burgerlijk bestuur, waarschijnlijk van verschillenden rang.

\section{Zang XVI.}

Deze Zang bevat een voortzetting van 't onmiddellijk voorafgaande, waarbij in meer bijzonderheden getreden wordt. Het eerste vers, in de maat Wilāsinì, luidt als volgt :

1 Dit moet de beteekenis zijn van 't onverstaanbare pāhudhama; vermoedelijk een bedorven lezing, waarvoor ik geen geneesmiddel kan vinden. 
Krama nika sang bhujangga n-umareng digantara dang $\bar{u} \mid$ hiuilahilān swakāryya jagadona tanswang alaha | wĕnang ika yan pakon nẹpatï sing parāna ta kunang | - magěhakĕnang Çiwāgama phalanya tanpanasara || l ||

D. i. "Het was regel voor de geleerde geestelijken (b h u ja ng ga's), die eertijds naar andere landen gingen, dat het hun niet geoorloofd was hun eigen zaken te drijven, waardoor het belang der wereld ten zeerste zou lijden. Doch wel mochten zij, wanneer de vorsten het bevalen, overal, waar ook, heen gaan om 't Cliwaïsme te bevestigen, opdat het niet zou afdwaleu."

Kunang ika sang bhujangga Sugatabrateki karĕngö | apituwin ajña hajy atana ${ }^{1}$ sing sapārana nikā ${ }^{2}$ |

hinilahila sakulwan ikanang tanah Jawa kabeh | taya ring usāna Boddha mara rakwa sambhawa tinūt $\|2\|$

D. i. "Maar de geleerde geestelijken van de Buddhistische belijdenis, van hen luidt het verhaal dat zij volgens koninklijke bevelen verkort 2 waren (in hun vrijheid) om overal heen te gaau: 't geheele Westen van Java was voor hen verboden (gebied), omdat er, naar het heet, in den ouden tijd geen Buddhisten waren. ${ }^{3} . "$

Omtrent de feiten uit de geschiedenis, waarop de dichter 't door hem beweerde steunt, verkecren wij geheel in 't duister. Zooveel is zeker, dat hij aangaande den bloeienden toestannd van 't Buddhisme, juist in 't Westelijk gedeelte van Java, in vroeger eeuwen althans, onkundig was. Zonderling genoeg. Intusschen mag men wel aaunemen, dat wat hij naar 't verleden plantst, den feitelijken toestand in zijn eigen tijd weerspiegelt.

Tuhun ikanang digantara sawetan ing Yawadharā |

i Gurun i Bāli mukya kawĕnang parāna nikā |

samaya niraug mahāmuni Bharadha rakwa ta mapagĕh |

la wan ika sang munīndra Kuturan prakāça karĕngö \| 3 \|

D. i. "Maar de andere landen ten Oosten van Java: Gurun, Bali, enz., mochten zij bezoeken. De groote Wijze Bharadha deed zijn gelofte getrouw gestand, en de uitmuntende Wijze Kuturan, zooals algemeen bekend is."

Over de twee hier vermelde geestelijke heeren, vindt men ook

1 Met atana weet ik niets an te vangen; ik veronderstel, dat men lezen moet atuna.

2 Gedrukt paranantikā.

3 De zin der woorden sambhaw a tinūt ontsnapt me; misschien: „zoover men kan nagaan". 
in andere bronnen 't een en auder opgeteekend. In KBWdb. II, 159 , leest men dat Mpu Kuturan ${ }^{1}$ een oudere broeder was van Mpu Bradah (Bharadha), die op Bali leefde. Omtrent Bradah weet de Tjalon Arang, de titel van een tooverspreuk, waardoor men iets kau vernietigen en weder geheel herstellen, te vertellen, dat zekere heks, Tjalon Arang geheeten, die onder Er-Langga zou geleefd hebben en bij de Baliërs onder haar bijnaam Rangdèng Girah (Dirah of Djirah) bekend is, strijd gevoerd heeft met Mpu Bradah. ${ }^{2}$ Het is duidelijk, dat het vertelsel van dien strijd eerst in zwang kan gekomen zijn, toen Bradah reeds een legendarisch persoon geworden was. Wat Kuturan betreft, wordt door v. c. Tuuk (t. a. p.) uit een Pamĕntjangah getiteld geschrift, aangehaald een zinsnede, luidende : paryangan pangastana sang Mpu Kuturan ing uni, waar nieuw aangekomen geestelijken logeeren. Blijkbaar is met parhyangan, heiligdom, bedoeld het klooster, waar reizende monniken tijdelijk huisvesting vonden. De uitdrukking "nieuw aangekomen", wa hu raw uh, is een vertaling van āgantuka (bhikṣu, Pāli bhikkhu) in tegenstelling van ā wāsika, die in zijn eigen klooster verblijf houdt; het pangāsthāna van Mpu Kuturan is wat men in 't Sanskrit en Pāli noemt zijn ā wāsa. De taak, die Mpu Kuturan in opdracht had te vervullen, wordt uitvoeriger beschreven in de Usana Bali. Een gedeclte van hetgeen v. d. Tuuk (t. a. p.) daaruit aanhaalt, zij hier medegedeeld: Tĕḍ un sira Mpu Kuturan ring Majapahit, magawe pradeça ring Bali, katular saking Majapahittingkahing deça, magawe gagaḍuan ring pradeçan sang ratu Bali. Munggah ring rajapurana ${ }^{3}$, ring praçasti aciacian ing deça odalan deça, sma(?), ring caturjanma makanda kĕnakĕnane; d. i. "Mpu Kuturan kwam af uit Majapahit, stichtte 4 dessa's op Bali, naar 't voorbeeld van de wijze waarop in Majapahit de dessa's ingericht zijn; hij gaf leengronden uit in de dorpsgemeenten van den koning van Bali. Volgens den koninklijken giftbrief ${ }^{5}$

1 De titel Mpu, eig. Heer, is zeer gewoon bij namen van geestelijke heeren; men kan dien dus gevoegelijk vergelijken met ${ }_{n}$ Dom", bijv. in Dom Pitra, en ons "Dominé".

2 Zie KBWdb. I, 635.

s In oudere spelling räjap ūraṇa.

4 Misschien „om te stichten", daar in de jongere taal van 't geschrift, het conjunctief-teeken verwaarloosd kan zijn.

${ }^{5} \mathrm{R}$ äjapūrana wordt in 't KBWdb. wel vermeld, maar niet verklaard. Mijne vertaling berust op de beteekenis "begiftigen", welke Skr. pūrayati meermalen heeft. 
moesten verschillende tinsen (of: contributies) opgebracht worden, en wel zoo, dat de vier kasten respectievelijk daartoe verplicht waren."

Uit de hier medegedeelde gegevens, in hun onderling verband beschouwd, is op te maken, dat Bharadha en Kuturan twee in hoog aanzien staande Buddhistische monniken waren, die niet alleen in geloofszaken hun werkzaamheid ontplooiden, maar ook belast waren met de inrichting op Bali van 't landelijk stelsel, zooals dat op Java bestond. Ten minste van Mpu Kuturan wordt dit getuigd. Als ik het wel begrijp, behelsde de koninklijke giftbrief de aanwijzing van gronden op Bali, welke ten bate der Buddhistische geestelijkheid werden afgestaan en waarmede dorpsgemeenteu beleend werden tegen opbrengst van bepaalde tinsen door alle vier klassen der gemeentenaren. ${ }^{1}$

Ter loops zij opgemerkt, dat het een anachronisme is, wanneer in de bovenvermelde Tjalon Araug Bradah in den tijd van ErLangga gesteld wordt. Het komt meer voor, dat vermaarde heerschers met elkander verward worden.

$\mathrm{Na}$ deze uitweiding keeren wij terug tot het gedicht, waar de verdiensten der zendelingen in vage termen geroemd worden.

Karaña ni sang bhujangga tinitah lakwa rasika |

ikang inutus mangulwan angawetan akrama huwus |

saji saji ring lumakwakěn i sājña sang narapati |

sawiku sadā yan āngujar aweh rěsĕp ing umulat $\| 4$ \|

D. i. "De werkzaamheden van de geleerde geestelijken, die in last hadden er op uit te gaan, uitgezonden waren naar 't Westen en naar 't Oosten, hebben volkomen goeden voortgang gehad, door de voorkomendheid ${ }^{2}$ dergenen, die al de bevelen des konings ten uitvoer brachten: als monniken, die altijd wanueer zij 't woord voeren, degenen, die hen zien, behagen inboezemen."

In deze regels ligt duidelijk opgesloten, dat de geestelijken op last des konings werden uitgezonden ter bevordering ook van politieke doeleinden. Men begreep in 't oude Majapahit, dat men onderworpen bevolkingen allereerst door zachtheid moet trachten te winnen: een navolgenswaardig voorbeeld ook nog in onzen tijd. Dat tegen weerspannigen met gestrengheid moet opgetreden worden,

1 In 't oude Java en Bali zal, evenals in Indië, een deel der bevolking, het proletariaat zeker wel buiten elk kasteverband gestaan hebben en niet schotplichtig geweest zijn.

2 Ik ben niet zeker van de juistheid dezer vertaling. 
dat begreep men niet minder. Dit vernemen wij uit de nu volgende strofe :

Irika tang anyabhūmi kahĕmban ing Yawapurì| amatěhi sājña sang ṇ̣pati kapwa satya ring ulah| pituwi sing ājũalangghana dinon wiçî̀ṇ̣a sahana |

těkap ikanang watěk jaladhimantry aneka suyaça \| $\mathbf{5} \|$

D. i. "Toen voegden zich de andere landen, die onder de voogdij van Java's hoofdstad stonden, naar de bevelen van den vorst, alle trouw vau gedrag. Maar alwie de bevelen overtraden, werden beoorloogd en geheel en al verdelgd door de zeevoogden, van wie verscheidene zich beroemd maakten."

Men ziet, dat hier sprake is van weerspannige eilaudbewoners buiten Java. Om 't gezag te handhaven in 't wijduitgestrekte gebied, moeten de Javaneu natuurlijk een machtige vloot gehad hebben.

\section{Zang XVỊ.}

In de versmat Jagaddhita.

Sāmpun rabdha pagěh ny adĕg ṇ̣pati ri Yawadharaṇi jayeng digantara |

ngkāne Crî̀phalatiktanāgara sirān siniwi mulahakĕn jagaddhita | kîrṇ̣ekang yaça kîrtti dharmma ginawe nira'n anukani buddhi ning para 1

mantrì wipra bhujangga sang sama wineh wibhawa tumut akirtti ring jagat $\|1\|$

D. i. "De regeering van den vorst over Javaland, dat de andere landen veroverd had, was nu wèl bevestigd; in de stad Crî̀phalatikta troonde hij, waar hij streefde het heil der wereld te bevorderen. Verbreid was zijn roem en faam, en hij betrachtte gerechtigheid, waardoor hij 't gemoed van een ieder ${ }^{1}$ bevredigde. Staatsdienaren, priesters (of: Brahmanen), Bhujangga's, die alle rijk begiftigd werden, werden mede in de wereld beroemd."

Verder lezen wij :

Göng ning wîryya wibhūti kagraha tĕkap nṛpati tuhutuhūttama prabhu |

lìlā nora kasangçayān ira'n anamtami suka sakahaṛsa ning manah| kanyā sing rahajöng ri Janggala lawan ri Kaḍiri pinilih sasambhawa | āstām tang kahañang sakeng parapurāsing arěja wina we dalěm purî̀ || 2 ||

1 Dit schijnt bedoeld met para, hoewel dit woord eigenlijk "een ander, een vreemde", of zelfs "een vijand" beteekent. 
D. i. "Groot is de macht en pracht, die de vorst bezat, in volle waarheid ecn hooge heerscher. Gerust en onbezorgd geeft hij zich over aan geneugten naar hartelust; alle schoone meisjes in Djanggala en in Kadiri werden uitgekozen, zooveel als mogelijk; en ook van de uit vreemde landen buitgemaakten, werden alle die mooi waren, in 't vrouwentimmer van 't paleis gebracht."

De dichter vervolgt aldus :

Salwā ning Yawabhūmi tulya nagarì sasiki ri pangadĕg narādhipa | mewwiwu ng jana deça tulya kuwu ning bala mangidĕri kaṇṭa ning purî |

salwir ning paranūṣa tulya nika thāniwișaya pinahasukenaris | lwî̀ udyāna tikang wanādri sahananya jinajah ira tanpanangçaya || 3 ||

D.i. "Het land Java lijkt, over zijn geheele uitgestrekthcid, één enkele stad, onder de regeering van den Vorst; de bij duizenden en duizenden tellende landbevolkingen lijken kampen van troepen, die zich rondom de hoofdstad bewegen; al de andere eilanden (buitenbezittingen) lijken plattelandsgewesten, waaraan een behagelijk en rustig bestaan verzekerd is; als wandelparken zijn bosch en gebergte, die alle doorkruist worden zonder dat men eenig gevaar te duchten heeft."

De vierde strofe luidt aldus :

Bāryyan māsa ri sāmpun ing çiçirakāla sira mahasahas macangkrama | w wantĕn thāny angaran ri Sìma kidul i Jalagiri mangawetan ing pura |

rāmyāpan papunagyan ing jagat i kāla ning sawuug ika mogha tanpěgat |

mwang Wewe pikatan ri Caṇḍi lima lot paraparan ira tușța lālana || 4 ||

D. i. "Elke maand na 't einde van den kouden tijd, pleegt Hij op wandelingen rond te dwalen. Er is een dorp met name Sīma, zuid van Djalagiri naar 't Oosten van de hoofdstad; levendig is het daar, wijl de meuschen een gelofte volbrengen, ten tijde van onafgebroken feestvergaderingen; en Wewe Pikatan te Cạ̣ḍi lima (de Vijf Tjandi's) bezoekt Hij gedurig blij van zin."

De plaatsnamen in deze strofe is het mij niet gelukt te vinden; ze zijn zeker uiet ver van Majapahit te zoeken. Evenmin is mij recht duidelijk, welk verband er tusschen 't afleggen van geloften en drukke feestvergaderingen bestaat. Ik veronderstel, dat er sprake is van een bedevaart, waarbij eene talrijke menigte samenstroomt en van de gelegenheid gebruik makt om feest te vieren. De omstandigheid, dat die fecstvergaderingen bij den berg Djalagiri plaats 
hadden, herinnert aan 't meermalen in Buddhistische geschriften voorkomende giraggasamajjo, berg-feestvergadering ${ }^{1}$

Zeer zonderling is de plaatsnaam Wewe pikatan. Zou dit "lokeenden" beteekenen, zoodat wewe een oudere vorm ware van bebek? Maar, zoover als bekend, heeft we we gansch andere beteekenissen, die echter in 't geheel niet passen bij pikatan.

Wij lezen verder:

Yan tan mangka mareng Phalah marĕk i jöng hyang Acalapati bhakti sādara |

pantěs yau panulus ḍatĕng ri Balitar mwang i Jimuri Çilāhrit ālěngöng |

mukya ng Polaman ing Dahe kuwu ri lingga mara bangun ikā lanenusī |

yau ring Janggala lot sabhā nẹpati ring Surabhaya manulus mare Buwun || 5 ||

D. i. "Anders gaat hij naar Palah eerbiedig en nederig hulde brengende aan de voeten van den goddelijken Bergheer. ${ }^{2}$ Het is wel te begrijpen, dat hij zijn tocht dan voortzet naar Blitar, Djimur, in 't liefelijke Çilāhrit. ${ }^{3}$ In Daha werd in de eerste plaats Polaman, de kuwu (kampement), de Lingga _ 44 steeds bezocht. Wanneer de Vorst in Djanggala is, houdt hij steeds hof te Surabaja, van waar hij de reis voortzet naar Buwun."

Van de hier voorkomende plaatsnamen zijn eenige thans nog welbekend: Blitar en Surabaja, Ook Polaman is bekend als eigennaam van een plaats in de residentie Surabaja, zooals men zien kan uit KBWdb. I, 264, waar ook vermeld staat, dat Wukir Polaman de titel is van een gedicht, dat de befaamde Jaya Katong na zijn val, kort vóór zijn dood, vervaardigde. Hetzelfde bericht de Pararaton, blz. 24. ${ }^{5}$

Zoover ik heb kunnen nagaan, vindt men hier de oudste vermelding van Surabaya.

De dichter weidt nog verder uit over 's Konings reizen.

1 Vgl. Hardy in Album Kern, blz. 61, vgg.

2 Daar Acalapati, bergheer, synoniem is met Girindra, kan hier Çiwa bedoeld wezen.

s Çilāhrit, dichtbegroeide berg, behoeft niet noodzakelijk als eigennaam opgevat te worden.

4 Ik ben onzeker omtrent mara bangun ik $\bar{a}$, ten einde die op te richten, maar dat past niet recht bij het onmiddellijk volgende.

5 Vgl. de aanteekening van Brandes aldaar, blz. 104. 
Ring Çākākșatisūryya sang prabhu mahas ri Pajang iniring ing sauāgara |

ring Çākāngganagāryyamā sira mare Lasĕm ahawan i tīra ning pasir |

ri dwārādripanendu panglĕngĕng ireng jaladhi kidul atūt wanālaris | ngkāneng Loḍaya len Tĕtö ri Siḍemman jinajah ira langönya yenitung $\|6\|$

D. i. "In 't Çakajaar $1275^{1}=1353$ A. D. maakte de Heerscher een rondreis in Pajang, vergezeld door de gansche stad; in Caka $1276=1354$ A. D. ging hij naar Lasěm, den weg nemende langs 't zeestrand; in $1279^{2}=1354 \mathrm{~A}$. D. vermeide hij zich op den zuidelijken Oceaan, de reis voortzettende langs de wouden; hij doorreisde Loḍaya en Tĕtö en Siḍeman, waarvan hij de schoonheden opnam."

De ligging van Pajang, Lasĕm, Loḍaya is bekend genoeg; van Tĕtö en Siḍ̆man is alleen te zeggen, dat ze niet ver van Loḍaya gezocht moeten worden.

Door de toevoeging van jaartallen heeft de dichter, naar alle waarschijnlijkheid, willen doen uitkomen, dat in tegenstelling tot de kleinere reisjes, in de voorgaande strofen door hem vermeld, deze grootere tochten het karakter droegen van tochten, met de noodige statie - zonderling uitgedrukt door de woorden " vergezeld door de gansche stad" - , en gewichtige staatsgebeurtenissen waren. Nog duidelijker komt dit uit in de volgende strofe:

Ndān ring Çāka çaçāngkanāgarawi Bhādrapadamasa ri tāmbwang ing wulan |

sang Çrī-rāja sanāgarān mahasahas ri Lamajang angitung sa'zendriyan |

sakweh Çrī-Yawarāja sapriya muwah tumuti hajï sabhṛtya-wāhana | mantrī taṇḍa sa Wilwatikta nguniweh wiku haji kawirāja mangdulur || 7 ||

D. i. "Daarna in 't Çākajaar 1281 (= 1359 A. D.), in de maand Bhādrapa (Augustus-September), bij wassende maan, maakte Z. Maj. de Koning een rondreis naar Lamajang, alles in den omtrek opnemende; alle hooge vorsten van Java met gemalinnen waren mede met den Vorst, met dienaren en wagens; hoogere en lagere

1 Ti kan hier niet anders aanduiden dan 7. Hoe de lettergreep aan deze beteekenis komt, is mij een raadsel; elders is dit ti nog niet aangetroffen.

2 Pana, oor, heeft, gelijk elk ander woord van oor, de cijferwaarde $\operatorname{van} 2$. 
staatsbeambten van geheel Wilwatikta (Majapahit), alsook voorname monniken en dichter-vorsten wareu in 't gevolg."

Lamajang, voor 't meer gebruikelijke Lumajang, komt in 't gedicht nogmaals voor.

In de nu volgende strofe, vindt de dichter gelegenheid om over zichzelf te spreken, aldus :

Ngkān teking maparab Prapañca tumut anglěngĕng angiringi jöng nareçwara |

tan len saug kawi putra sang kawi samenaka dinulur ananmateng mangö |

dharmmādhyakṣa kasogatan sira těkap narapati sumilih ri sang yayah |

sakweh sang wiku Boddha mangjuru paḍangatuturakĕn ulah nireng dang $\bar{u}\|8\|$

D. i. "Nu was daar ook bij de persoon ${ }^{1}$ Prapañca bijgenaamd, die mede met verrukking onderdanigst den Vorst vergezelde. Het kan niet anders of dichters en zonen van dichters zullen alle gaarne gevolgd worden door wiê in 't dichten behagen scheppen. ${ }^{2}$ Als superintendent van de Buddhistische gemeente aangesteld door den Koning, volgde hij zijn vader op, wiens handel en wandel indertijd al de leidende Buddhistische monniken tot voorbeeld van navolging namen."

De schrijver treedt nu omtrent zichzelven nog in verdere bijzonderheden in de nu volgende strofe:

Ndān tingkah rakawi'n marĕk ri haji dug raray atutur asewa tan salah |

piurihnye hati rakwa milwa sapara ${ }^{3}$ narapati'n amalar kasanmata | nghing tapwan wruh apet langö pisan ingun tětěsa maminta gita ring karas |

nā hetunya kawarṇna ${ }^{4}$ deça sakamārggāngaran ika riniňci tūt hawan \|f 9 \|

D. i. "De dichter had de gewoonte, toen hij nog een knaap was,

1 Het vnw. iki, deze, duidt aan, dat de schrijver over zichzelf spreekt. Het is een nederige uitdrukking, waarvan 't eigenaardige verloren zou gaan, wanneer men het verving door "ik".

${ }^{2}$ In vrij dubbelzinnige bewoordingen geeft Prapañca m. i. te kennen, dat hij uit een geslacht van dichters stammende, vanzelf dichterlijke aandrift gevoelt; hetgeen kwansuis tot verontschuldiging moet strekken, dat ook hij als dichter optreedt.

3 Saparā voor saparan.

4 Verbeterd uit kamārṇna, wat niets is. 
voor den Koning te verschijuen en onderdanig zijne opwachting te maken, zonder missen. Het was zijn hartewensch den Vorst overal waar hij ging, te mogen vergezellen, hetgeen hem gelukkig werd toegestaan; maar hij wist nog volstrekt niet schoone tafereelen te bedenken, die men zorgen moet te doen uitkomen, wanneer men gedichten te boek stelt. Daarom zijn de strekeu, zoover als ze bereisd zijn, beschreven, dat wil zeggen, geregeld naar den gevolgden weg, afzonderlijk opgeteekend." ${ }^{1}$

$\mathrm{Nu}$ begint het relaas van de bezochte streken.

Tambe ning kahawan winarṇṇa ri Japan kuṭikuṭi hana caṇḍi sāk rĕbah |

wetan tang Těbu Pāṇḍawādri Daluwang Babala muwah i Kañci tan madoh |

len tekang kuṭi Ratnapangkaja muwah kuṭi Haji kuṭi Pangkajādulur |

Paṇjrak-maṇḍala len ri Pongging i Jingan Kuwu hañar i samīpa ning hawan $\|10\|$

D. i. "De eerste plaats van 't bereisde• gebied, welke beschreven wordt, is Djapan : tal vau monnikskluizen en sommige Tjanḍi's geheel in verval; ten Oosten Těbu ${ }^{2}$, Pāṇḍa wādri ${ }^{3}$, Daluwang ${ }^{*}$ en niet ver daar vandaan Kañci. ${ }^{5}$ Voorts de kluis Ratnapangkaja (Lotus van edelsteen), en de Koningskluis, benevens de kluis Pangkaja (Lotuskluis), Pañjrak-mañd̦ala ${ }^{6}$ en Pongging, Djingan ${ }^{7}$, Kuwu hañar (Nieuwkamp), dicht bij den weg.”

De lijst gaat voort als volgt :

Prāpteng dharmma ring Pañcaçāra tumuluy ḍatěng i Kapulungan sirāmĕgil |

ndān lampah rakawi'n lumāryy amĕgil ing Waru ri Hĕring i tīra tan madoh $\mid$

anggānggěhnya těkap bhațāra kuṭi ring Suraya pagěh mara cinārccakĕn |

1 Met andere woorden: de plaatsen en merkwaardigheden onder weg worden in den vorm van een lijst opgesomd.

2 Onzeker of het hier een plaatsnaam is, dan wel "suikerriet".

3 D. i. Pānḍawa-berg, naar 't voorbeeld van Pāṇḍawaparwata bij 't oude Rājag̣̣ha in Magadha, bekend uit de Buddha-legende.

${ }^{4}$ Als appellatief schors, papier uit schors, en priestermuts.

${ }^{5}$ Beter gespeld $K \bar{a} \tilde{n} c \overline{1}$; ook dit is de naam van een bekende stad in Zuidelijk Indië, ook Kāncīpura geheeten, d. i. Conjewaram.

${ }^{6}$ D. i. Kring der rondreizende muzikanten of smidsknechts; misschien een gereserveerd gebied of kampong van als Zigeuners levende lieden.

7 In de Pararaton 31,1 , heet de plaats Jinggan. 
nghing rakwa'n kasĕlang mulih amogha matutur atisambhrameng mangö || $11 \|$

D. i. "Hij kwam aan bij den graftempel te Pañcaçāra ${ }^{1}$; verder kwam hij te Kapulungan ${ }^{2}$, waar hij overnachtte. Daarop zette de dichter zijn tocht voort, overuachtte in Waru, in Hering, in Tira, niet ver van daar. ${ }^{3} \mathrm{Hij}$ is eenigszins verwant met den heer van de kluis te Suraya, hetgeen bij bespreking vast werd uitgemaakt. En zoo kwam het, dat hij een poos verwijlde, alvorens huiswaarts te keeren; doch weldra bedacht hij zich en ging hij met grooten ijver aan 't dichten."

De uitdrukking "bhațāra kuṭi" is eenigszins bevreemdend, daar "bhațāra" een zeer hooge titel is. Het kan ziju, dat die verre verwant van den dichter, om een of andere reden een persoon van gewicht was, een HoogEerwaarde kluizenaar.

Anggāngĕh, beter angganggĕh gespeld, want het bestaat uit angg ĕ + anggĕh, een voorbeeld van stam-reduplicatie volgens den regel, dat daarbij in 't eerste lid de medeklinker van den uitgang vervalt; bijv. kaywan wordt bij reduplicatie kaywaka $y$ w a n.

H. KERN.

1 Onjuiste spelling voor Pañcasāra, de vijf hoofdbestanddeelen, enz.

2 Deze plaats komt tweemaal voor in de merkwaardige oorkonde van Kṛtarājasa (als Prins: Raden Wijaya), medegedeeld door Brandes in Pararaton, blz. 79,82 .

3 Wellicht is bedoeld: „niet ver van 't strand.

NASchrifr. Het woord $\mathrm{gimbar}$ in Zang VIII, 3 is zeker wel hetzelfde als Sund. gimbar, maar in gewijzigde beteekenis, zoo iets als "ruim".

H. K. 